\title{
Daniel and Enoch: Two different reactions
}

P M Venter

Department of Old Testament Studies (Sec. A)

University of Pretoria

\begin{abstract}
The authors of Daniel 7-12 and of 1 Enoch 83-90 are identified as groups from the retainer class. Both groups belonged to the apocalyptic Hasidic movement. They differed in their reactions to the measures which Antiochus IV Epiphanes took against the temple and the Jews in 167 BCE. The Enoch group were inclined towards the activist stance taken by the Maccabees. The Daniel group chose for a modified apocalyptic form of asceticism.
\end{abstract}

\section{INTRODUCTION}

The meaning of a text is discovered when it is read '.. in terms of a specific culture, specific historical circumstances, a particular point of view' (Collins 1984:20). What is needed is an '... analysis, synthesis, and interpretation of the social as well as literary and ideological (theological) dimensions of a text, the correlation of these textualfeatures, and [an investigation into] the manner in which it was designed as a persuasive vehicle of communication and social interaction ...' (Elliott 1993:70).

Reid had this purpose in mind when he compared '... historical apocalypses with no otherwordly journey ...' (Reid 1989:5) from the second century BCE, as they are found in the books of Daniel and Ethiopian Enoch. Aiming at a comparison of their sociological settings, he used form criticism, social theory and anthropological analysis. The way in which he used form criticism is according to his mind the original way Gunkel himself used it. Form-critical analysis leads ipso facto to the question of the social setting of the text. This includes the general or typical background of the genre in question as well as the specific socio-historical setting of the text. Gunkel used the term 'Sitz im Leben' exactly for these two goals: to reconstruct the social setting of the genre and to determine the historical origin of the text in question. According to Reid, however: 'Modern form critics have tended to confuse these two goals so that much form-critical research insufficiently distinguishes between the sociological setting of the genre and the historical setting of the particular text' (Reid 1989:9).

Reid was correct when he applied a multidisciplinary approach. He used formcriticism, a religionsgeschichtliche approach which sees eschatology as '... a major factor in the social construction of reality in the Jewish communities of the early second 
century BCE' (Reid 1989:14), sociological theories of group forming, and Apocalypticism as seen from a mantic perspective. Davies, in his study of Daniel in 1993, working with literature as a social medium used by classes or groups to express their values and symbolic universe, remarked that form criticism would not suffice to describe the social background of the book. In the case of Daniel not only the genre of the apocalypse is used but several genres. The selection and combination of genres cannot be explained merely by form-critical methods. 'Once it is accepted that literature is a scribal activity, and thus inevitably associated with a certain class, and that this class has available to it a multitude of genres, which may be selected for a number of reasons, the value of a form-critical approach for a sociological analysis is substantially diminished' (Davies 1993:350). Form critical investigation includes the study of Sitz im Leben and the specific setting ought to be studied with a variety of sociological and historical methods. When Reid made a sharp distinction between the sociological setting of the genre and the historical setting of the particular text, he went the wrong way. Form criticism studies typical forms in typical settings. This should be supplemented by a study of the specific historical situation. These two aspects could be studied separately, but in the end neither of them can be clearly understood without the other. It is not sufficient when Reid comes to the conclusion that the three historical apocalypses of 1 Enoch reiate to a community which is anti-Hellenistic, representing a type of activistic, utopian apocalypticism, while the community of the Daniel apocalypses is not so much anti-Hellenistic as it is anti-Antiochene, representing a quietistic, revolutionist/nonresistant type of apocalypticism. When LaCocque (1993) disagrees with Reid's opposition between an utopian Enoch and a revolutionist Daniel with a revolutiơnist mentality, it is because he thinks that Reid and other scholars like Lebram and Goldstein postdates the anti-hellenistic opposition too much. There was already some conflict with Hellenism in Jerusalem prior to the Antiochene persecution of 167 BCE. There was an existing Kulturkampf between the Hellenists and the opposition in Jerusalem which became a political schism in which groups not only protected the status quo, but was awaiting the kingdom of God from several points of view. The dramatic event of Antiochus's reform and his ban on everything Jewish was '.. crowning a conflict unequivocally set on a cultural-religious level ...' (LaCocque 1993:323). The groups represented in Enoch and Daniel were acting in a situation which already had a long history of conflict and amidst a society which consisted of many members and different groups. The person/s or groups responsible for creating Daniel and Enoch should be studied within a much larger framework, socially and historically, than Reid did. This is what this article intends to do. 


\section{THE JEWISH COMMUNITY IN HELLENISTIC TIMES}

\subsection{Structure of the community}

According to Saldarini (1988:36f) the Jews were people living in an agrarian society being part of a large agrarian, bureaucratic and partly commercialized aristocratic Hellenistic empire. Steep hierarchy and great inequality existed, while control and wealth were in the hands of the few. There were two major classes separated by a wide gulf. The large peasant class produced the food. The small elite class organized the society in such a way that the peasants were forced to produce a surplus which could be extracted from them usually by burdensome taxes. In exchange the rulers protected the peasants so that they. could plant and harvest crop without disturbance, destruction or theft.

These two factions of society, according to the theory of Lensky (cf Saldarini 1988:39), could be further subdivided into nine significant classes. In the upper class there was the ruler, governing class, retainer class, merchant class and priestly class. In the lower section were the peasants, artisans, unclean or degraded persons and the expendable class.

\subsection{The ruler}

The ruler was the king of the Hellenistic empire to which Judah belonged. Having been part of the Ptolemaic kingdom since 312 BCE, Judah became Seleucid property in 198 BCE. Antiochus III defeated the Egyptian general Scopus at Paneion in Upper Galilee in 200 BCE and took over Palestine. Antiochus III was succeeded by Seleucus IV Philopater in 187 BCE. He was in turn followed by Antiochus IV who reigned since 176 BCE. It was during his reign that the events occurred which are reflected in the literature of Daniel and Enoch.

\subsection{The governing class}

Next to the ruler the small governing class (1-2\% of the population) was made up of hereditary aristocrats and appointed bureaucrats. In Jewish society the governing class was formed by the chief priests, large landowners, notable elders and major officials. With no middle class in between, they ruled over the lower class of peasants, that is, some 95\% of the population (cf LaCocque 1993:318-9). The duty of the upper class was to protect the peasants from outside aggression. In return the peasants were taxed $30-70 \%$ of their crop.

They formed what Freyne calls the '... hellenized aristocratic party within Judaism ... (1980:262). In Jerusalem the Hellenistic emperors governed through alliance with this ruling class, the priestly aristocracy. At their head stood the high priest. He was 
the political and economic representative as well as the ethnic and religious head of the Judeans (cf Horsley \& Hanson 1985:9-10) The high priest was responsible for the collection of taxes. He was assisted by the chief priestly families. Their custody of the treasure in the temple, which served as a deposit bank as well as a centre of worship, provided the upper priestly class with a firm financial basis for its increasing power and influence, both internally and externally.

The ruling class consisted of two opposing factions: the pro-Ptolemaic conservative Oniads who had a theocratic ideal for Judah and the radical reformist pro-Seleucid party of the Tobiads. In the time before the beginning of the reign of Antiochus IV (late 175 , early $174 \mathrm{BCE}$ ) the high priest came from the Oniads. During the time of what Goldstein calls the 'critical period' (1981:71), from. 175-163 BCE, starting with Jason's high priesthood extending down to the time when the Jews received the letter from Antiochus $V$ which restored to them their laws and their temple, the Tobiads took over the governing role. Their leader was Jason, brother of the high priest Onias III. They used Antiochus IV Epiphanes' ascent to power in 176 BCE to carry out a reform. The new Seleucid king Antiochus IV followed strange policies. He started establishing republican institutions on the Roman model, forming an Antiochene republic with an Antiochene citizenship. He invited his subjects to accept Antiochene citizenship either as communities or as individuals. Jason took opportunity to accept this citizenship and exploited the possibility of becoming an Antiochene citizen in 175/174 BCE, taking along the inhabitants of Jerusalem. He purchased the high priesthood for himself offering Antiochus considerably more than the usual tribute of 300 talents. He was made high priest, replacing Onias. He also changed the name of Jerusalem into the name Antioch and organised a citizen body recruited from the upper priestly families and gentry interested in modernising the city. The king issued decrees permitting the goals desired by Jason and his followers. What Jason asked for was permission to establish typical Hellenistic institutes like a gymnasium and an ephebic organisation allowing the participants to become Antiochene citizens being part of the Greek commonwealth. This move made Jerusalem into a polis whose citizen-body enjoyed self-government and participated in commerce between cities and shared cultural institutions and celebrations with other cities of the empire.

Another turn of events came in $172 \mathrm{BCE}$ when Menelaus, leader of the radical Hellenizing faction outbidded Jason for the high-priesthood and sent him into exile in the Transjordan. To raise the tribute promised to Antiochus he raised the taxes. Having difficulty in raising the needed tribute, he conspired with his brother Lysimachus to embèzzle the temple treasures. and vessels. This brought about popular resistance in which Lysimachus himself was killed. Antioch returned from an Egyptian campaign in 
$169 \mathrm{BCE}$ and plundered the temple himself. Menelaus and his faction were forced to take refuge in the citadel and Jason himself came back in an effort to retake Jerusalemfor himself. Antioch saw this as an revolt and, returning from Egypt where he lost against the Romans, he ransacked Jerusalem on the 7th of December 168 BCE, killing thousands of peoples and captured many Judeans whom he sold as slaves. The Phrygian mercenaries whom he put in control of the city were not able tot resist the following resistance and Apollonius took the city on a Sabbath in 167 BCE and established a military colony in the city. Antiochus decreed the compulsory abandonment of the traditional Jewish customs and observance of the law.

\subsection{The retainer class}

Against this background the role of the third category, the retainer class, becomes much clearer. The governing class maintained its position with the assistance of what Lensky calls 'the retainer class' (cf Saldarini 1988:37). These retainers were mostly townspeople who served the needs of the governing class as soldiers, educators, religious functionaries, entertainers and skilled artisans. Their roles were military, governing, administrative, judicial and priestly. The retainers; perhaps $5 \%$ of the population, shared to some extent in the life of the elite, but not in its direct power. 'They were a residual group dependant on the governing class and participating in its life to some extent' (Saldarini 1988:38). Because these people could easily be replaced by other individuals they lacked power. They could, however, influence society and gain power when the governing class ceased to be effective rulers and left matters in their hands.

Among the groups of the retainer class who could influence society were the religious functionaries and scribes who acted as bureaucrats, educators and major and minor officials. 'Groups with a strong religious base could acquire independence andpower within society by a stress on universal values and ideology and by relatively open membership' (Saldarini 1988:6). These groups stood separated from the traditional territorial and status hierarchy, being conservative in support of the regime, sometimes promoting a critical stance towards society. 'Such a relatively independent religious establishment is firmly political and typically tries to dominate society through the establishment of a canon of sacred books, schools to interpret the texts, educational organizations to spread knowledge, and the fostering of a total world view' (Saldarini 1988:6-7). Creators and interpreters of literature are also, according to the theory of Greenblatt (cf Davies 1993:346), manipulators of knowledge who exercise through this control of knowledge power over society. In this literature the literate class/es express/es their interests, the symbols and values of society they uphold, social reality as seen from their viewpoint. 
The way this literature and society relate can be explained following the theory of the anthropologist Redfield of the great and the little tradition. According to Redfield the upper class differentiates itself from the lower class by holding monopoly of power and authority, forming the correct kinship groupings and keeping highly valued achievements. Included in the elite group are literati (acting as retainers) who are the official carriers of the classical written tradition. This tradition provides the social system with a sophisticated and elaborate justification for its existence and continued survival. The social structure include the relations of cultural influence and example between the elite half and the peasant half of the whole larger social system. The elite exhibits to the peasant the highly valued achievements and provides the peasant's social system with a sophisticated justification for its existence and survival. The culture of a peasant society is not autonomous, but forms an aspect of the civilisation of which it is a part. The peasant culture must continuously come into contact with the centres of civilisation to maintain itself. In this regard the terms 'great tradition' and 'little tradition' are being used.

In a civilisation there is a great tradition of the reflective few, and there is a little tradition of the largely unreflective many. The great tradition is cultivated in schools or temples; the little tradition works itself out and keeps itself going in the lives of the unlettered in their village communities. The tradition of the philosopher, theologian, and literary man is a tradition consciously cultivated and handed down; that of the people is for the most part taken for granted and not submitted to much scrutiny or considered refinement and improvement.

(Redfield 1956:70)

These two traditions are independent and effect each other continuously.

Great epics have arisen out of elements of traditional tale-telling by many people, and epics have returned again to the peasantry for modification and incorporation into local cultures. The ethics of the Old Testament are out of tribal peoples and returned to peasant communities after they had been the subject of thought by philosophers and theologians.

(Redfield 1956:71-2)

Great and little traditions can be thought of as two currents of thought and action, distinguishable, yet ever flowing into and out of each other. 
During the time of Antiochus IV a division took place among the retainers responsible for cultivating the tradition. According to Horsley \& Hanson (1985:3) the common people '... held ideals of what life should be like, and a memory which informed and buttressed those ideals'. While a professional group of scribes and priests reflectively systematized and codified these important memories and stories, as well as laws and official documents, there was still a '... peasants' cultural memory ...' (Horsley \& Hanson 1985:4) which played a role in their historical actions and interactions.

\begin{abstract}
Through the collective memory of the people, eventually in the form of biblical stories, these circumstances of the peasantry (free of overlords and kings, independent of foreign domination, living under the rule of God in a just and egalitarian social order) became a reference point for subsequent generations, a utopian ideal over against which later subjection to kings and foreign empires was measured and found contrary to the will of God.
\end{abstract}

(Horsley \& Hanson 1985:6)

When Antiochus IV started his persecution it became impossible to uphold the great tradition. The temple was dese-crated and temple personnel were forced to take part in a syncretistic religion in which sacrifices were brought for Zeus Olimpos. The great tradition could not supply the answers and solutions to the problems with which the Jews were confronted. The 'collective memory of the people', the little tradition, became more important.

As power centre of Palestine the city Jerusalem had a different social structure. The governing classes lived there, while the bulk of the ancient society, the peasants, were absent from the city (cf Saldarini 1988:46). The city was used for political, administrative, military, religious and educational purposes, making most of the activities in the city fit these goals. The only peasants from the lower classes living there were those who served the upper class and took care in the city of the menial tasks necessary for life and luxury. Social conflict in the city was restricted to the governing class and their retainers. The people responsible for the little tradition were absent. New groups, movements and ideas had to be formed to continue the ideals and memories of the little tradition. 


\subsection{Reactions from the retainer class}

In the crisis brought about by the actions of Antiochus and the ruling classes, there were several responses. One response was the anti-Hellenistic response recorded in the book of Jubilees. According to Goldstein this is a contemporary source, being written between autumn 169 and spring 167 BCE, almost in the immediate aftermath of Jason's reforms (1981:79). On the other hand I and II Maccabees are giving judgments after the fact. 1 Maccabees views these events from the perspective of a rigorous interpreter of the commandments in the Torah and '.. is propaganda for the Hasmonean kings and may well reflect the opinions of earlier members of the dynasty' (Goldstein 1981:81). Another response to the crisis is found in the upsurge of apocalypticism. 'Desperate to understand their seemingly impossible situation, some faithful Jews sought divine revelation ... to explain why their life circumstances had become so intolerable and what plan God might have to deliver them' (Horsley \& Hanson 1985:16-7). Apocalyptic literature such as the Assumption of Moses, 1 Enoch 85-90 (The Animal Apocalypse), and the book of Daniel were written in connection with the reform crisis and resistance to the Hellenistic persecution. According to Goldstein Enoch 85-90 was written even earlier than Jubilees (1981:81). He is of opinion that Daniel 7-12 was written at various times between spring 167 and summer 163 BCE (cf Goldstein 1981: 81). This literature gives an indication of some Jews' interpretation of the situation and their motivation in resisting the persecution. An important motivation was that memory of freedom of the little tradition. The great tradition was in a turmoil. Although the Jews remained faithful to God, they were persecuted because they adhered to the law. Their own priestly aristocracy was in alliance with the imperial authorities. 'It was before necessary to find some more transcendent interpretation of their persecution. They were acutely in need of a revelation of their history that was turning out so disastrously' (Horsley \& Hanson 1985:17-18). The fact that the deliverance and receipt of revelation took literary form, shows that people who were knowledgeable in the ancestral traditions and who could write (sages teachers, scribes) became involved in the resistance. As the gulf widened between the 'assimilationist priestly aristocracy' (Horsley \& Hanson 1985:18) and the rest of the retainers and peasantry outside Jerusalem, the role of scribes and sages not attached to the temple establishment would have to become increasingly important. As the crisis came there were groups of wise men (Maskilim) such as those who produced the book of Daniel (11:33) who were ready to make many understand. 'With their experiences thus placed in eschatological perspective via apocalyptic visions, Judeans could find some purpose and meaning in their suffering and death, whether in martyrdom for the faith (as with the Maskilim), or in armed resistance to the oppressive imperial decree (as with the Hasidim and Maccabees)' (Horsley \& Hanson 1985:18-19). 
The sources of this literature could have been individuals. These individuals were, however, people serving as retainers fulfilling a social position is society. They should be studied as people belonging to a group or class. Gottwald's (1993:10) remark is of importance: 'An important service of a sociological reading of the Bible is to plot the contours of class consciousness and class strategy - when and how they are expressed, ignored, or suppressed - in order to give a convincing social context to the diversities of biblical texts and religious developments'.

\section{THE HASIDIM}

Apocalyptic literature was the result of the upsurge of an apocalyptic movement. According to Albertz, it was due to an inherent revolutionary force present in the Yahwe religion right from the beginning, that a '... neue apokalyptische Widerstandstheologie ...' (1992:634) developed in Hellenistic Palestine during the second century BCE. Although the influence of prophetical eschatology as well as wisdom can be seen in the literature of this group, their social-historical setting can not be found in either of these circles. The 'Trägerkreise' (Albertz 1992:635) of this literature were '... Angehörige einer intellektuele Führungsschicht ...' (Albertz 1992:637) opposing the Hellenizing section of the elite and standing in solidarity with the poor and conservative people of the city and the land. Albertz thinks that the group responsible for the apocalyptic literature can be looked for among the so called Hasidim, seen not as a conventicle, but as an influential group of scribes. They gave '... den bis dahinmarginalisierten eschatologischen Erwartungen eine enorme Durchschlagskraft in den antihellenistischen und antihasmonäischen Aufstandsbewegungen und eine gesellschaftliche Breitenwirkung, wie jene sie zuvor nie gehabt hatte' (Albertz 1992:637). In his extensive study on the Hasidim LaCocque (1988 \& 1993) used a sample of Jewish literature from the second century BCE. He pictures the Hasidim as '... a social movement ...' (LaCocque 1993:320), a '... voluntary association ...' (LaCocque 1993:319), a '... social movement in transition ...' (LaCocque 1993:338), an effort by a large number of people to solve collectively a problem that they feel they have in common, '... a movement rather than a constituted sect, a stance rather than a defined doctrine' (LaCocque 1993:335) .... In Esler's terms they were '... a group of intellectuals extremely unhappy with the situation, and who saw themselves as speaking for faithful Israel ...' (1993:191). Rowland defines the Hasidim as '... a loosely defined group, possibly related to the continuation of visionary activity found in some later prophetic oracles which looked to the future as the time when the promises made by God to the prophets would be realized' (Rowland 1982:211). Gottwald thinks that the Hasidic party were probably less a long-defined 'party' than rather '... a coalition of anti-Hellenistic 
tradionalists whom the pressure of circumstances threw together. In that coalition there were probably many points of view represented, among them the apocalyptic' (Gottwald 1985:588:9).

While the writing down of tradition usually serves as a means of power for the upper class, it also happened that the upper classes were prone to leave behind the Jewish world and to adopt the surrounding Hellenistic culture. In this process the lower classes remained more faithful to traditional Judaism and, by reaction against the new ideologies brought into Jerusalem by the Tobiads and Oniads, hardened ancestral stances. 'Time and again, the cadres around such popular reactionary subversion are disenfranchised, or at least powerless, clerics. The mix of popular, even proletarian, milieus with lettered, scribal elements, has often been the ferment of revolutionary movements in Jewish history' (LaCocque 1993:318). Scribes and teachers from the retainer class took it upon themselves to continue the ideals and memories of the little tradition. Having had no real presence of peasants in Jerusalem, they took upon themselves the role of the peasants to cultivate the little tradition. The use of language gave to them the power to influence other members of society. By means of the literature they created they tried to persuade other members of the retainer class and even members of the ruling class to adopt their value system and their view on the society.

This movement started in the eastern diaspora (cf Collins 1984:36). At first they channelled their energies in a common opposition to the Hellenization of ancestral traditions. At this stage they constituted a loosely organized entity. 'The Asidaioi were first an eschatologically oriented movement, a utopian dream, unified only in their antiestablishment position. They themselves knew certainly more about what they were opposed to than what they agreed on' (LaCocque 1988:45). As Hellenism was progressively permeating all aspects of Palestinian Jewish existence and local communal traditional social organizations started to disintegrate, voluntary association were formed. At first these Hasidic associations were hesitant and insecure as to their stance of opposition and to the appropriate action to be taken against their enemies. When in the end Hellenism came to corrode Jewish faith itself, these people got more and more intentional in their struggle against an increasingly corrupt Temple personnel, including the pontifex maximus. The acme of the revolt was reached with the unprecedented religious persecution mounted by Antiochus IV. It was at this stage that decisions were to be made which changed the movement into several sects. With Judas Maccabee's uprising, however, internal dissension developed amongst them whether or not to interpret the Hasmonaen enterprise eschatologically. In the end they split into two branches, the Pharisees representing the tolerant branch and the Essenes being the intolerant section of the Hasidim. The Book of Dream Visions (1 Enoch 83-90) and Daniel 7-12 falls exactly at the point of bifurcation in the Hasidim movement into the Hasidim/ Essenes and the Hasidim/Pharisees (cf LaCocque 1993:326). 
For LaCocque the connection between Hasidim and priests is evident. In his opinion apocalypticism may even have originated in priestly circles within the Hasidicmovement (cf LaCocque 1993:336). Scribes are also associated with the Hasidim. Collins suggested in The Apocalyptic Imagination written in 1984, that the Enoch traditions are the products of scribes who were distressed by the encroachment of Hellenism and the consequent erosion of traditional customs and aggravation of class divisions. Enoch himself is presented as a scribe in the Enoch book. In the Hasidic-scribal milieu popular lore and mythological imagery, represented in the form of angelology and a dualism of good and evil were united. This is due to the Hasidic movement being a popular movement, '... conducted by sages and spiritual sophisticated leaders (maskilim and masdiqim)' (LaCocque 1993:336-7).

\section{HASIDIC GROUPS}

Within the ranks of the Hasidim different groups or sects were formed. B Wilson distinguishes between seven types of groups according to their diverse responses to the problem of evil, or to the world at large. Both working with the same theory of Wilson on apocalyptic groups, LaCocque and Reid differ from each other as to the identification of which group the authors of Enoch and Daniel would belong to. Reid understands the community of the historical apocalypses in 1 Enoch 93, 91:12-17, the Dream Vision in 83-4 and the Animal Apocalypse in 85-90 as representing an 'utopian mentality' which stands in conflict and confrontation with the larger culture, the '... unrighteous assimilationist Jews' (Reid 1989:68). According to his view revolutionist/ non-resistant apocalypticism in Daniel, understanding social change as exclusively God's work, stands against utopian/activistic apocalypticism in 1 Enoch which acknowledges that social change must originate with God, but stresses that the community of faith must help implement God's eschatological promises. The focus of identity in 1 Enoch is the supra-functional social group of the communion. God is the origin of the change, but the community of faith is understood to be a potential vehicle for the actualization of God's eschatological promises. 'The utopian mentality is not against the present system of governance per se, but against the whole political system. 1 Enoch is not merely anti-Seleucid; it is also anti-Hellenistic' (Reid 1989:133). On the other hand the focus of identity in the Daniel passages is the community. More traditions from the outside are used than in Enoch. 'The revolutionist perspective of the Danielic historical apocalypse is not against the political system, as such, but rather is against a specific political power. It is anti-Antiochene, perhaps pro-Ptolemaic, certainly specifically anti-Seleucid, rather than anti-Hellenistic' (Reid 1989:134).

LaCocque disagrees with Reid's opposition between an utopian 1 Enoch and a revolutionist Daniel with a revolutionist mentality. LaCocque would rather side with Förster and Maier working on a much broader basis, historically and sociologically. 
He would like to understand the groups in Enoch and Daniel as different Hasidim sects taking part in an ongoing struggle of long standing, but drawn together by the dramatic event of Antiochus's reform, when the struggle came to a crowning conflict on a cultural-religious level during the sixties of the second century BCE (cf LaCocque 1993:323). Keeping in mind the forming of an activist group leading the Maccabean revolt the identification of the groups in Enoch and Daniel can neither be done on the simple basis of who joined the Maccabees and who not. It is too simple to oppose a pacifist stance with a militant one and to decide that the Enoch or Daniel group belonged to them. As Horsley \& Hanson (1985:20) indicated, there is too much '.. uncertainty whether the term Hasidim/Hasideans (pious or devoted ones) used in some of our sources refers generally to those who remained actively devoted to the law, or more precisely to a primarily scribal or priestly group or party, who provided leadership in the rebellion and produced apocalyptic literature'. Hasidim groups can not be confined to a group of Sabbath pacifists and/or a supposed scribal or priestly group who were ready to negotiate a peace as soon as their limited cultic or religious purposes could be attained (cf Horsley \& Hanson 1985:20). There may have been two orders amongst Hasidim, both being militant/pacifist, as there would be later two orders of Essenes. 'It can therefore be speculated that militancy and pacifism may have co-existed without creating between their supporters a radical division, as one or the other attitude resulted from an option for praxis dependent upon interpretation of the eschaton' (LaCocque 1993:323). Keeping in mind the decisive impact of eschatological expectations upon apocalyptic quietism or utopian participation in events, the Maccabean revolt was initially seen by the participating Hasidim as the end of time, the final war. They were persuaded that the Maccabean struggle was the Holy War par excellence, the eschatological war against the final enemy. When it became clear that the Maccabees were engaged in a personal pursuit of glory and power, the Hasidim were the first to seek peace (1 Maccabees 7:12-17). It became clear that these events were penultimate and the Hasidim turned to peace with the reigning powers. But '... even prior to the time in which some of the Hasidim decided to collaborate with the priestly Maccabean movement of military opposition, the author of Daniel had, appa-rently, taken some distance from such an option' (LaCocque 1993:324).

\section{ENOCH AND DANIEL}

Against this background we can read and understand the books of Daniel and the relevant parts of Ethiopian Enoch. As opinions differ on the dates of the composition of these books, we shall not primarily take the date of composition as our point of departure, but rather apocalyptic literature which alludes to the events of Antiochus' reforms between the years 167 and $164 \mathrm{BCE}$. 


\subsection{Enoch}

Since the first translations of Ethiopian Enoch the book was divided into different sections:

* Book 1. The Book of the Watchers (1-36)

* Book 2. The Book of Parables (37-71)

* Book 3. The Book of Heavenly Luminaries (72-82)

* Book 4. The Book of Dream Visions (83-90)

* Book 5. The Book of exhortations and woes (92-105)

* Book 6. The birth of Noah (106-107) (cf Nickelsburg 1984:266-7).

Already in 1821 Laurence had the presumption in his translation called 'Mashafa Henok Nabiy, The Book of Enoch the Prophet', that these different parts dated from different periods (cf Uhlig 1984:468) and therefore from different sources. The Book of Dream Visions (1 Enoch 83-90) forms the fourth section. It reflects the events of the Maccabean revolt. 90:13-15 refers to the combat at Beth Horon in 164 BCE (cf 2 Maccabees 11:6-12) and 90:16 refers to the events of the year 164 (cf Uhlig 1984: 673). Uhlig (1984:673) calls the book of visions ' $\ldots$ der am stärksten in sich geschlossene teil der Henochsammlung ....' As the Animal-Apocalypse presupposes the rise of the Hasidim and probably the Maccabean uprising (90:11f) and no reference is found to any further historical events, Rowland (1982:252) thinks '... that we are probably right to deal with these chapters in isolation'. Comparison with 1 Enoch 1-36 leads '... zu dem Ergebnis, dass dieses Stück aus phraseologischen wie inhaltlichen Gründen einem anderen Tradentenkreis als das Buch der Wächter und die Epistel Henochs entstammt' (Uhlig 1984:673).

The Book of Dream Visions (Book 4) is comprised of a first vision report (83-4) and the Animal Apocalypse (85-90). 1 Enoch 85-90 presents the history from creation down to the Maccabean period in the form of a dream symbolised by animals. The history ends with the Maccabean struggle which serves as a prelude to the dawn of the new age. The rise of the Hasidim (90:6) is a prelude tot the final attack of the heathen nations upon the people of God. Israel triumph and the righteous carry out the act of judgement (90:19) (cf Rowland 1982:156f). According to Reid's form critical analysis the genre of 83-4 is a dream vision report (cf Reid 1989:57f). Three traditions are found in this section: the fall of the angels, call of Enoch and intercession. This section is intended to legitimate the teachings of Enoch which follows in 85-90. This section also conveys two theological messages: the extent of salvation is restricted to 
those who are part of the posterity of Enoch, and is not universal; this salvation is founded in the power and wisdom of God. The second part (85-90), is constituted by three literary types: historicized fable/theriomorphic historical allegory, apocalyptic timetable, report of judgment. As genre the Animal Apocalypse is a mixed form, with the theriomorphic allegory setting the tone making the unit an historical allegory.

Albertz deducts from the contents of the Animal Apocalypse (1 Enoch 85-90) that the Trägerkreis of the apocalypse was a section of the Hasidim who was very much inclined towards the viewpoint of the Maccabees. In 1 En 85-90 the Maccabees are hailed as those who changed the fate of the people, sent by God to start the great final war. According to 1 En 90:6-19 the Hasidim who joint forces with the Maccabees, developed '... eine martialische apokalyptische Propaganda ...' (Albertz 1992:666) among the rebels. The Maccabees, although not apocalyptically orientated, but rather based on the old tradition of war in the name of Yahweh, welcomed this influence because it boosted the morale for fighting. The Hasidim took part in the war, because it presented to them the opportunity '... die bisherige Erfolglosigkeit ihrer theologischen Aufklärungsarbeit zu überwinden und ihrer Niederlage gegen die Hellenisten in einen Sieg umzumünzen' (Albertz 1992:666). Changing apocalyptical instruction into political-military propaganda also brought about a change in the original simple UrzeitEndzeit typology. The old universal horizon of apocalyptic was not enough to provide a thorough reason for the participation of the Jews in a fight for freedom. Within the universal framework (85:3-89:9, 90:20-38) the authors therefore included a summary of all of the history of Israel (89:10-90:19). As Rowland puts it: 'The readers of the apocalypses are permitted to see that the experiences of the present must be related to the totality of human history, whose course is entirely directed by God' (Rowland 1982:143). Their thoughts were marked by '... einen radikale Geschichtsdeutung, wobei die Gegenwart als Gerichts- oder doch Zorneszeit gewertet wurde, als Zeit, die zur Aufrichtung des Gottesreiches führen würde' (Uhlig 1984:492). For them history is shown to be characterised by violence and oppression. The authors indicate that Israel was all through its history victim of unjust violence. Although Israel was punished for his apostasy, the foreign kings superseded their limits by oppressing Israel. They were to be punished for this in the end. As victim of superfluous oppression Israel had the right to overpower their oppressors as it happened in the time of Saul and of David and as it occurred in the Maccabean revolt. 
Die apokalyptische Präsentation der Geschichte Israels stand somit ganz im Dienst der legitimation des aktiven Widerstands: Hatten Jahwe und Israel auch schon in früheren Epochen zur Befreiung des Gottesvolkes von Unterdrückung zusammengearbeitet, dann war auch der makkabäische Freiheitskampf notwendiger Bestandteil des eschatologischen Befreiungsprozesses.

(Albertz 1992:667)

But not only the revolt was legitimised this way, but also the participation of the pious scribes was justified. Previous deliverance were connected to instructions of revelations $(89: 1,89: 41)$. Apostasy in Israel from the Torah is set on one footing with blindness towards the revelations. The militant wing of the Hasidim had to declare their purpose with the war of liberation: did they intend to regain and rededicate the temple, or did they intend freeing themselves from Hellenistic oppression? The author/s of the Animal Apocalypse, rather different from the Hebrew Daniel, do/es not refer to the profanation of the temple by Antiochus. Their intention with the revolt was a fight for political freedom. According to his/their view the second temple was defiled and unpure from the start. In the end of time God would build a new temple in which He will live again. "So lässt sich die "Tier-Apokalypse" von ihrem Gesamtduktus her gut als engagierte Stellungsnahme des politisch aktiven Flügels der Chasidim innerhalb der makkabaïschen Aufstandsbewegung erklären' (Albertz 1992:668). Reid, as already stated, designated the group of the Animal Apocalypse as a 'communion', a 'suprafunctional group' who stands in conflict and confrontation with the larger culture generating a whole system of knowledge forming their own symbolic universe. The world outside the communion is seen as tainted and the world inside is seen as a parallel reality to the otherworld/heaven. They have an '... utopian mentality ...' (Reid 1989:68). The goal of history is to bring secularisation to an end.

Their system of values is conservative as it attempts to return and maintain traditional Jewish values and concepts. It was a community who treasured the writings of Ezekiel. 1 Enoch 85-90 was influenced directly or indirectly by the meaning of Ezekiel and Jeremiah. Uhlig (1984:491) is correct when he locates the Trägerkreise of this literature in the '... apokalyptischer Kreise, die das prophetische Traditionsgut in ihren "pietistischen" Konventikeln pflegten und erweiterten'. The imagery and the issue in 1 Enoch 89:59-67 is the same as in Ezekiel 34. In both cases the leadership of the community has failed to carry out the responsibility incumbent on the office of leadership of the Jewish community. The bad shepherds are the leaders who, instead of protecting the community, have used their office for the acquisition of the trappings of the elite. 
A major issue in the text is whether or not the shepherd-ruler, whomever he/she is, will maintain Jewish law, which requires that the king or queen should reign with equity, toleration and justice. From this Reid draws the conclusion that the

... stance presented in 1 Enoch 85-90 is typical of anti-Hellenistic propaganda outside of Palestine, but perhaps, even more importantly, the Animal Apocalypse makes clear that the community to which the author belonged was neither pro-Seleucid or pro-Antiochene. It appears from the text of the Animal Apocalypse that it comes from a community which is simply extreme critical of Jewish overlords and their Jewish henchmen.

(Reid 1989:65)

Thus Reid's point of view that the community of 1 Enoch is not against Ptolemies or Seleucids per se, but against all Hellenistic leadership and control.

Keeping in mind the theory of LaCocque (1993:326) that the Book of Dream Visions (1 Enoch 83-90) and Daniel 7-12 falls exactly at the point of bifurcation in the Hasidim movement into the Hasidim/Essenes and the Hasidim/Pharisees. Uhlig is probably correct when he sees some of the characteristics of the later Qumran community already present in the Enoch section of the Hasidim. According to Uhlig (1984:492) they were an '.. in die Isolation getriebenen Kreise ....' Largely corresponding to the literature found at Qumran, ' $\ldots$ ist an eine der Qumrangemeinschaft ähnliche Gruppe als Verfasserschule von Hen(äth) zu denken ...' (Uhlig 1984:492).

\subsection{Daniel}

Turning to Daniel 7-12, several theories on the forming of the book are held. Reid (1989:68f) thinks that older theriomorphic allegories $(7: 2-7,8: 3-12)$ were used in both Daniel 7 and 8. No clear references to Antiochus IV is found in them and this suggests a pre-Antiochene origin. The terminus ad quem for both chapters is the time of Antiochus. In Daniel 10-12 there are clear references to Antiochus and this material is assigned to the period of his reign. References to Antiochus are found in the redactional additions to chapters 7 and 8 as well. This would indicate that the author of Daniel 10-12 may have been the editor of Daniel 7 and 8. Daniel 9 and 12:5-13 come from a period later than 7-8 and 10-12. Reid therefore discerns 3 stages of redaction in Daniel 7-12: the pre-Antiochus stage, earlier than $174 \mathrm{BCE}$; the Maccabean redaction of the book including references to Antiochus IV in chapters 7-8 and 10-12; the postAntiochene stage represented by the prayer (Dniel 9) and the epilogue (12:5-13). 
Albertz (cf 1992:651f) divides the history or early apocalyptic literature into four phases. During the 'Vorphase' (3rd century-ca 221BCE) a Greek collection of 'Bekehrungserzählungen' (Dn 4-6*LXX) from the Egyptian diaspora were made. During the first main phase (ca 221-200) an Aramaic Daniel book (Dn 2-7*) was formed as well as the Watchman's book (1 Enoch 1-36). In the second main phase, which occurred during the Maccabean revolt (167-160 BCE) the existing book of Daniel and the Animal Apocalypse (1 Enoch 85-90) was compiled. In the 'Nachphase' (cf Albertz 1992:651) the Letter of Enoch including the Apocalypse of the Weeks (1 Enoch 91-105) was compiled. Daniel, according to Gottwald (1985:594) reflects events and the career of Antiochus correctly up to the beginning of $165 \mathrm{BCE}$, but a third Seleucid invasion of Egypt is expected which did not occur (11:42-3) and it is unaware of Antiochus's campaign in the east during which he died. The temple also still awaits rededication.

The second part of Daniel (7-12) consists of five parts:

* A '... theriomorphic historical allegory' in Daniel 7 (Reid 1989:83);

* Six constituent literary elements forming a theriomorphic historical allegory in chapter 8 as well;

* A prayer in Daniel 9;

* A 'dynastic prophecy' in Daniel 10:1-12:4 (Reid 1989:109):

* An epilogue (12:5-13).

The symbolic universe of the authors of Daniel, their construction of reality as it is communicated by means of symbols (cf Davies 1993:350), can be studied from different angles. From symbols like 'Book', 'Court' and 'Secret', deductions can be made about the Daniel group. An ethos of writing, even an ideology of writing is indicated by the symbol 'Book' in Daniel. Writing symbolises authority, earthly as well as heavenly. As we concluded before, scribes and teachers from the retainer class had to continue the ideals and memories of the little tradition. They were in a position to influence other members of society by means of the literature they created. They referred to themselves as the 'maskilim' (Dn 11:33, 35) - the teachers who had the task to teach the masses, the 'many' (Dn 12:4, 10). 
The historical situation in Jerusalem under Antiochus, the power struggle between the Oniads and Tobiads of the ruling class, the eventual Maccabean revolt by the priests, all of this brought them into conflict with several other groups in society. This could have been any one from Antiochus, the ruling class of the Tobiads and Oniads, the Maccabean revolutionaries, or even, as suggested by Lebram (1983:183f), another group of eschatological teachers who had an over enthusiastic Naherwartung.

Reid deducts from the historical apocalypses in Daniel 7, 8, and 10:1-12:4 that the Daniel group had a revolutionist perspective being rather anti-Antiochene, than antiHellenistic (cf Reid 1989:xii). They were more than any thing else against the political power of Antiochus IV. The remark of Davies (1993:354) in this regard gives a probable reason for this attitude: 'The hatred of Antiochus that is evident in Daniel suggests a particular interest, however, and loss of political power may well be a motive'. Following Reid's line of anti-Antiochene thinking, a glimpse inside the sociological mentality behind the material in Daniel 7-8 and 10-12 is given by the connection of political chaos with blasphemy and the sin of hubris. Antiochus is depicted as the evil leader of whom it is assumed that he will be a major force in social change - thischange is not in line with the theological stance of Daniel's community. The reaction of the community to the sins of Antiochus is that of nonparticipation. 'The value expression of the response is thus the sacralization of humility with respect to one's participation in social change' (Reid 1989:115). God is the author of change and nowhere is it even hinted that the community should try to alter the course of history. Legitimation is provided for the ensuing and final disintegration of the reign of Antiochus. An implicit exhortation is given that the members of the community of faith should mentally and spiritually, not overtly and physically, posture themselves against Antiochus. 'Contrary to the utopian community of the historical apocalypses of 1 Enoch, where the righteous are given the sword of judgment (1 Enoch 91:12) and instructed to play an active role in social change, in Daniel 10-12 active participation in social change is ridiculed (Dn 11:34)' (Reid 1989:121).

This pacifist attitude, however, can also be understood in non-Antiochene terms as an effort to take their stand against another Hasidic group, or even the Maccabees themselves. It could have been a matter of '... entpolitisierenden Programmatik ...' (Albertz 1992:671) where the author of the Hebrew Daniel wants to show his readers '... dass die eigentliche Auseinandersetzung nicht auf politischem, sondern auf religiösen Gebiet ablief' (Albertz 1992:671). The armed revolt was meaningless as Antiochus was to continue his oppression and to find his end in a war from which the archangel Michael will save his people (cf Dn 11:34, 35, 36-39, 40-45, 12:1). The present time is rather a time of trial. The militant Hasidim are putting the people to the test. Only those who resist the political revolt will be saved. 
Der Daniel-Apokalyptiker optierte somit für einen rein religiösen, verbalen und gewaltfreien Widerstand, und er warb unter den Kollegen des quitetistischen Flügels der Chasidim dafür, die turbulente Gegenwart als die entscheidende Bewährungsprobe zu begreifen, die über die teilhabe am endzeitlichen Heil entscied $(12,10)$.

(Albertz 1992:669)

Another way of looking at the Daniel group is suggested by the way in which LaCocque narrows the gap between an absolute quietistic and an absolute activistic stance (cf LaCocque 1993:323). Like the rest of the Hasidic movement the people of the Daniel group were persuaded by the decisions of Antiochus IV and by the Maccabean revolt that the eschatological war against the enemy had started. Gottwald points out that the stance the apocalyptists of Daniel took towards events in their days had not been pacifist. 'If they were Hasids, however, it is likely that they did join in the defensive wars against the Seleucids and took part in the political infighting among Jews' (Gottwald 1985:594). There was a difference, however, because the author/s of Daniel distanced him/themselves from the military option of opposition taken by the priestly Maccabean movement (cf LaCocque 1993:324). It seems as if they chose for total pacifism. However, this supposed pacifism '... may be a misimpression derived from the apocalyptic view that even the utmost that humans can do is minimal compared to the decisive act of God' (Gottwald 1985:594). These apocalyptic devotees were activists, probably combatants, within the limits of their situation, as can be seen from the fact that they did not discard or repudiate their apocalypse when it became clear that Daniel's visions were wrong about the end of time. Indeed '.. they took an active role in resisting Antiochus, not by fighting but by spreading the revelations contained in these visions' (Collins 1984:38). They ' $\ldots$ preferred martyrdom to active resistance ...' (LaCocque 1988:30). Their stance is one of '.. a behaviour which submits itself to the social, as well as to the historical, events, and does not propose to interrupt them by force' (Lebram 1983:186). This attitude can be called 'an apocalyptic modification of ascesis'. In a time of overwhelming profanity and desecration of the temple with no possibility for cultic atonement they practised asceticism refusing to participate in revolutionary rebellion. This does not mean that they were totally against all forms of military activity. The cataclysmic events of the end time are seen as active military events. The Maccabees are not totally ostracized for their militant activities. It is rather a matter of choice. They were '... quietists, concerned to preserve purity and to commune with the angelic world' (Collins 1984:37), waiting for the events of the end time to be started from heaven. 
This links to another symbol of the symbolic universe of Daniel: the 'Court'. Although the Daniel group were not living at the court of the king, the '... court remains the centre of interest of the entire book, its values affirmed and its importance for political life maintained' (Davies 1993:355). 'The court is a positive symbol, the natural home and setting of the authors' imagination' (Davies 1993:356). Reid is correct in saying that the community of Daniel was not generally anti-Hellenistic. 'The use of the Graeco-Persian historical schema shows a community that is open to Hellenistic-Persian concepts' (Reid 1989:90). But being a community in which mantic historicism flourished, espousing the ideology of spatial dualism (as can be seen by the use of angels), the earthly court is always linked tot the heavenly court. The kingdoms of God and of human monarchs are represented as simultaneous and not contradicting. In principle, however, they are seen as incompatible and the sovereignty of God is manifested in the end (cf Davies 1993:359f). Cognitive dissonance under the circumstances created by Antiochus' measures are dealt with by using the mechanism of secrets. In contrast to the historical apocalypses in Enoch where conflict and confrontation with the world are encouraged and action is foreseen, Daniel withdraws from active confrontation with reality. Confrontation is avoided, knowing through mantic activity that God will bring about the end of the king. Unlike Enoch, Daniel is characterised by his mediation of secrets, he is a decipherer. Characteristic to the Hebrew Daniel is also the speculation with numbers. Although the Animal Apocalypse also divided the world history into several periods, Daniel exceed this numbering the periods in terms of years. Based on the information in Jeremiah 29:10 and 25:11f that it would take 70 years for Jerusalem to be restored, Daniel reworks this into a period of seventy week years. By doing this he wanted to show that the time has been formerly fixed by God (9:24) and nobody can change it (11:14). A second aim of his was to show that the oppression under Antiochus was destined to come to an end. Consolation like this was needed by groups who followed passive resistance. Those who showed active resistance did not ask the question of how long it will take, because they intended to bring it to an end by themselves.

So lassen sich auch die für das Danielbuch eigentümlichen Datierungsversuche, die der von den meisten Oppositionsgruppen erwarteten eschatologischen Wende sehr viel mehr den Charakter eines fixierbaren Weltendes gaben, aus der quietistischen Frontstellung seiner Trägergruppe erklären'

(Albertz 1992:672) 
These secrets and calculations also functions as a mechanism for group definition, marking those who are privy to the secret and therefore have power from those who are outsiders. Although the secrets in Daniel are there for public consumption, it was rather meant for insiders who could read and for internal consumption to reinforce the world-view of insiders and not to persuade outsiders. The secrets are only open in a specific sense (cf Davies 1993:359-60).

Another indication of the relation of the Daniel group to other groups can be found in the reference to the temple. The blasphemous assault on Yahweh and his sanctuary (7:25, 8:11f, 25, 11:31) plays an important role in Daniel. This '... starke Konzentration auf die Tempelschändung, die die hebraïsche Danielapokalypse von der 'TierApolaypse' unterscheidet ...' (Albertz 192:671) gives expression to the self identity of the group. Daniel reflects a priestly perspective, but, remarks Davies (1993:359), the temple '... is present in the book of Daniel essentially in its absence'. Conventional temple piety is intended in the book, but it is rather the role of the temple in sanctification than the temple itself which plays a role. 'But while foreign imperium is destined to be replaced by direct divine rule, the role of the Temple is to be replaced by other activity, exemplified by the behaviour of the maskilim - intercession, teaching righteousness, suffering' (Davies 1993:361).

\section{CONCLUSION}

Comparing the Daniel group with the Enoch group, Reid points out four ideological/sociological features common to the apocalyptic texts of both Enoch and Daniel:

* both use prophetic traditions;

* they all reflect mantic activity and legitimate their social programs on the basis of mantic experience;

* mantic experience is perceived as communication between this world and the heavenly world, breaking down the separation between them;

* using theriomorphic allegory and dynastic prophecy the communities using them were aware of literary traditions of Canaan, Mesopotamia, Persia and Greece (cf Reid 1989:132-3).

To this we can add the sociological remarks that both of them belonged to the Hasidic movement found within the retainer class. Both were in conflict with not only the ruler Antiochus, but also with the members of the governing class, be it the Tobiads or the 
Oniads. Furthermore, they differed with each other on the correct reaction and steps to be taken under the circumstances created by Antiochus IV's ordinances. Both groups included scribes and sages as members, trying to uphold the little tradition under circumstances where the officials of the great tradition were not in a position to continue it, and under which the great tradition itself was not sufficient for dealing with circumstances.

In broad outlines Reid is correct to summarize the difference as revolutionist/nonresistant apocalypticism understanding social change as exclusively God's work standing against utopian/activistic apocalypticism which acknowledges that social change must originate with God, stressing that the community of faith must help implement God's eschatological promises (cf Reid 1989:133). This, however, should be understood within a much broader context. Albertz pictures the differences as coming from an apocalyptic theological debate. Comparing Daniel and 1 Enoch 85-90 it becomes clear for him

\begin{abstract}
... dass der Streit um die richtige Einschätzung der leidvollen Gegenwart ud die richtige Handlungsalternative für die Zukunft in der Makkabäerzeit ganz wesentlich auf dem Boden der apokalyptischen Theologie ausgefochten worden ist. Die Apokalyptik bekam in den Jahren zwischen 167 und 162 v. Chr. kurze Zeit eine beherrschende Rolle in der offiziellen Jahwereligion, weshalb sie sich ab dieser Zeit in ganz unterschiedliche Gruppen und Literaturformen ausbreitete.
\end{abstract}

(Albertz 1992:672)

The Hasidim group responsible for the Book of the Dream Vision in 1 Enoch 83-90 were very much inclined towards the activist Maccabean position, seeing in their proposed actions the opportunity to propagate their brand of apocalyptic interpretation. They wanted to maintain and advance traditional Jewish values including prophetical eschatology. They represented something of the exclusivism and overheated Naherwartung of their Qumran descendants. God's apocalyptically revealed plans should be realised here and now by being God's active co-workers in fighting the ungodly powers.

The Daniel group, on the other hand, were the teachers who had to teach the 'many' what to do. They were indeed against Antiochus, not so much against his person, as rather against his symbolic value. He represents all powers of evil. The fight against these powers is primarily fought by God and his angels. The role of humans can only be minimal compared to the decisive acts of God. They therefore opted for an 
'apocalyptic modification of ascesis'. They actively resisted Antiochus IV's decisions by not taking part at all in any of the social events of that time. Active confrontation is avoided and all action is retracted to the world of knowing that God is in power and man has to wait upon him. They would rather withdraw from the public sphere, being a temple for themselves, living a life of sanctification, righteousness and teaching, as well as suffering if this need to be.

A bifurcation occurred between these two branches of the one spiritual family of Hasidim, the one branch becoming the Hasidim/Essenes, the other the Hasidim/Pharisees (cf LaCocque 1993:326). The book of Daniel became part of the tradition of the Pharisees and due to their influence and power became part of the Hebrew canon. The book of Enoch on the other hand, did not become part of their tradition, but was used in the Essene community along with Daniel, where it was copied and parts of it found in the caves of Qumran. Whether it was pure coincidence that an pacifist apocalyptic tradition became part of the Hebrew canon, rather than an activist apocalyptic tradition, no one would be able to tell.

\section{Works Consulted}

Albertz, R 1992. Religionsgeschichte Israels in alttestamentlicher Zeit, Teil 2: Vom Exil bis zu den Makkabäern. Göttingen:-Vandenhoeck \& Ruprecht.

Collins, J J 1984. Daniel with an Introduction to Apocalyptic Literature. Grand Rapids, Michigan: Eerdmans.

Davies, P R 1993. Reading Daniel Sociologically, in Van der Woude, A S (ed) 1993, The Book of Daniel in the light of new findings. Leuven: Leuven University Press. Elliott, J H 1993. What is Social-Scientific Criticism? Minneapolis: Fortress Press.

Esler, P F 1993. Political Oppression in Jewish Apocalyptic Literature: A SocialScientific Approach. Listening 28/3, 181-209.

Freyne, S 1980. Galilee from Alexander the Great to Hadrian 323 BCE to 135 CE. A Study of Second Temple Judaism. Notre Dame, Indiana: Glazier \& University of Notre Dame Press.

Goldstein, J 1981. Jewish Acceptance and Rejection of Hellenism, in Sanders, E P, Baumgarten, A I, Mendelson, A 1981. Jewish and Christian Self-definition, Volume Two. Aspects of Judaism in the Graeco-Roman Period. 64-114. London: SCM Press.

Gottwald, N K 1985. The Hebrew Bible: A Socio-Literary Introduction. Philadelphia: Fortress Press.

Horsley, R A \& Hanson, J S 1985. Bandits, Prophets, and Messiahs: Popular Movements in the Time of Jesus. Minneapolis: Winston Press.

LaCocque, A 1988. Daniel in His Time. Columbia: University of South Carolina 
LaCocque, A 1988. Daniel in His Time. Columbia: University of South Carolina Press.

1993. The Socio-spiritual formative milieu of the Daniel Apocalypse, in Van der Woude, A S (ed) 1993, The Book of Daniel in the light of new findings. Leuven: Leuven University Press.

Lebram, J C H 1983. The Piety of the Jewish Apocalyptists, in Hellholm, D 1983, Apocalypticism in the Mediterranean World and the Near East: Proceedings of the International Colloquim on Apocalypticism Uppsala August 12-17, 1979. Tübingen: JCB Mohr.

Nickelsburg G W E 1983. Social Aspects of Palestinian Jewish Apocalypticism, in Hellholm, D 1983, Apocalypticism in the Mediterranean.World and the Near East: Proceedings of the International Colloquim on Apocalypticism Uppsala August 1217, 1979. Tübingen: JCB Mohr.

- 1994. s v Enoch, Book of. The Interpreter's Dictionary of the Bible, Supplementary Volume. Nashville: Abingdon Press, 265-9.

Redfield, R 1956. Peasant Society and Culture: An Anthropological Approach to Civilization. Chicago \& London: University of Chicago Press.

Reid, S B 1989. Enoch and Daniel: A Form Critical and Sociological Study of the Historical Apocalypses. Berkeley, California: Bibal Press.

Rowland, C 1982. The Open Heaven: A Study of Apocalyptic in Judaism and Early Christianity. London: SPCK.

Saldarini, A J 1988. Pharisees, Scribes and Sadducees in Palestinian Society: A Sociological Approach. Wilmington, Delaware: Michael Glazier.

Uhlig, S 1984. Apokalypsen: Das äthiopische Henochbuch, in Jüdische Schriften aus hellenistisch-römische Zeit, Band V. Lieferung 6. Gütersloh: Gütersloher Verlaghaus Gerd Mohn. 